\title{
Incorporating Remote Sensing Techniques To The DRASTIC Index To Assess Groundwater Vulnerability In The Mining Area of the Rio Sonora Aquifer in Northwestern Mexico
}

DENISSE Archundia ( $\nabla$ denissearchundia@yahoo.com.mx )

Universidad Nacional Autonoma de Mexico https://orcid.org/0000-0003-4957-7153

Victor Vidaña-Guillen

Universidad Nacional Autonoma de Mexico Instituto de Geologia

Juan Valenzuela-Munguia

ESTACION REGIONAL DEL NOROESTE DEL INSTITUTO DE GEOLOGIA - UNAM

Francisco elizandro Molina Freaner

instituto de ecologia unam

\section{Research Article}

Keywords: Metal contamination, groundwater, aquifer vulnerability, DRASTIC, remote sensing

Posted Date: December 1st, 2021

DOI: https://doi.org/10.21203/rs.3.rs-1025046/v1

License: (c) (1) This work is licensed under a Creative Commons Attribution 4.0 International License.

Read Full License 


\section{Abstract}

Groundwater metal pollution is a major concern for societies, especially in areas where the mining industry is important. Index-based techniques, as the DRASTIC index, are often used to assess the intrinsic groundwater vulnerability and could be modified to evaluate the aquifer vulnerability to specific contaminants. Mines, mining wastes and related features are detectable with remote sensing techniques. In this work we evaluate the vulnerability of the Rio Sonora Aquifer to metallic pollution by the traditional DRASTIC method and by the addition of a land use (LU) parameter in which possible sources of metals (detected by remote sensing) were considered (DRASTIC $+L U$ ). The methodology allowed us to locate possible sources of metallic contamination. The Sonora River channel showed the higher vulnerability in both calculated vulnerability indices (DRASTIC and DRASTIC $+L U$ ). Generally, the addition of the land use parameter caused a decrease in vulnerability but also a local increase where possible sources of metals were found. Thus, the modified method facilitated the identification of highly vulnerable areas which is relevant to better protect the studied aquifer.

\section{Introduction}

Groundwater is a valuable resource for human life and economic development. Its quantity and quality are of vital importance in arid and semi-arid areas, where the climatic conditions are characterized by low rainfall and high evapotranspiration, impacting surficial water resources and the aquifer recharge. The concept of groundwater vulnerability was first introduced by J. Margat in 1968; today it is of importance for the protection of groundwater resources. Assessing the vulnerability of an aquifer permits the identification of areas that are more susceptible to being contaminated, allowing to carry out effective protection measures and management plans for pollutants or wastes. Vulnerability assessment is really relevant as remediation of aquifers would be difficult and expensive (Aydi, 2018; Yin et al., 2013).

The intrinsic vulnerability defines the vulnerability of an aquifer to a variety of pollutants, independently of their nature, and it is related to the aquifer's features (hydrological, geological, and hydrogeological) (Oke, 2020). In that sense the vulnerability depends on the resistance of the aquifer itself when receiving pollutants from outside, the lower the resistance, the greater the vulnerability. Influencing factors are: depth to groundwater; net recharge rate; aquifer media; topography; vadose zone; hydraulic conductivity; aquifer thickness; and, pumping density rate in case of over-pumping (Abu-Bakr, 2020).

Aquifers will have different reactions to different pollutants due to their physicochemical characteristics. In those cases, it is more appropriate to talk about the specific vulnerability which defines the vulnerability to a specific contaminant or group of contaminants considering the contaminants' properties and its interaction with the aquifer (Gogu and Dassargues, 2000; Voutchkova et al., 2021).

Many methods have been developed to assess the groundwater vulnerability; they can be classified into three types: simulation methods, statistical methods, and index methods. The index-based techniques have the advantage that they do not depend on data availability or similarities (Barbulescu, 2020), being 
widely used. One of the most widely used index-based methods is the DRASTIC index, developed by the United States Environmental Protection Agency (EPA) to assess the potential for groundwater contamination (Aller, 1987). DRASTIC considers seven parameters: Depth to water table (D), net Recharge $(R)$, Aquifer media (A), Soil media (S), Topography $(T)$, Impact of the vadose zone (I), and hydraulic Conductivity (C) which, together, form the acronym.

Frequently, new parameters are added to the seven main hydrogeological parameters of the DRASTIC index. Additional parameters used by authors include: land-use (Kozłowski and Sojka, 2019), lineament (Abdullah et al., 2015), proximity to rivers, residential areas and roads (Aydi, 2018), hydraulic parameters (Lappas, I and Matiatos, I, 2014), redox state of the aquifer (Voutchkova et al., 2021), adsorption capacity of soils (Jr and Viero, 2006), contamination index (Cd) and heavy metal pollution index (HPI) (Haque et al., 2018). The DRASTIC index defines the aquifer intrinsic vulnerability; nevertheless, contaminant specific methods have been developed based on it. Thus, DRASTIC modifications have been undertaken to assess the groundwater vulnerability to nitrate (Jia et al., 2019; Voutchkova et al., 2021), pesticides (AlMallah and Al-Qurnawi, 2018; Thapa, 2018) and mining pollutants (Barbulescu, 2020; Haque et al., 2018; Tiwari et al., 2016).

Groundwater contamination related to the mining industry is an important global issue. Sulphide oxidation and the associated acid mine drainage (AMD) or acid rock drainage (ARD) is considered as one of the main water pollutants in many countries that have historic or current mining activities. AMD is prominent in both active and abandoned mining sites (Simate and Ndlovu, 2014). Mining areas are distinguished by the presence of waste dumps, mine tailings, water storage ponds, access roads and heap leach pads. These features are common indications of mining impacts to the surrounding areas and possible sources of metals. Some of these features are clearly detectable with remote sensing techniques (Werner et al., 2019). Indeed, many efforts have been undertaken to detect mining wastes, its impacts and site remediation by remote sensing (Balaniuk et al., 2020; Buczyńska, 2020; Connette et al., 2016; Firozjaei et al., 2021; Hao et al., 2019; Khosravi et al., 2021; McKenna et al., 2020). Normalized difference vegetation index (NDVI) is mostly used in vegetation growth research (Wang et al., 2021), it is calculated as the level of greenness using imagery. NDVI is also a useful tool for distinguishing the boundaries of vegetated terrain from tailings impoundments, which the NDVI primarily assigns negative pixel values (Firozjaei et al., 2021; Schimmer, 2008; Zeng et al., 2017).

To our knowledge, this is the first attempt to evaluate groundwater vulnerability to metallic pollution by the addition of a land use parameter in which possible sources of metals are considered to provide greater certainty to the vulnerability assessment at mining areas. We applied a supervised classification method to detect possible sources of metals on the area based on the NDVI values of known mining sites, mining wastes and mineralized areas of the study site.

The aims of the present work were: (i) propose a new method combining remote sensing and the DRASTIC procedure (modified DRASTIC method), (ii) identify possible sources of heavy metals (active and inactive mines, mining wastes and mineralized areas) by a remote sensing work using a supervised 
classification procedure based on $\mathrm{NDVI}$, (iii) assessing the ground water vulnerability to metal pollution at the mining area of The Rio Sonora basin and, (iv) comparing and validating the results obtained by the DRASTIC method and the proposed modified DRASTIC method.

\section{Materials And Methods}

\subsection{Study site and context}

The Rio Sonora aquifer is located in northwestern Mexico at the state of Sonora (Fig. 1), covering an area of about 12,615 km2. The area accounts for a population of 23,261 inhabitants (CIAD, 2013) from Aconchi, Arizpe, Banámichi, Baviácora, Huépac, San Felipe de Jesús and Ures municipalities. Groundwater major use is for agriculture, followed by industrial and domestic usage.

It is an unconfined aquifer; its lateral limits correspond to intrusive igneous rocks of the granitic type and extrusive rocks of the rhyolitic and andesitic type. In some areas, such as the Ures and San Felipe de Jesús valleys, the Báucarit formation emerges, which is a conglomerate complex with medium to low permeability. The Rio Sonora Aquifer is a porous-medium consisting of unconsolidated cobbles, gravels, and sands with good granular porosity; thus, good permeability is restricted to the riverbed and tributary streams (CONAGUA, 2015). The aquifer receives considerable amounts of water related to the summer rainfall which occurs during July and August; this water input corresponds to approximately $43.26 \mathrm{hm}^{3}$ year $^{-1}$. Due to the extraction of water for human and industrial uses and natural processes such as evaporation, evapotranspiration or underground flow (towards other basins or the sea), an output of approximately $57.12 \mathrm{hm}^{3}$ year ${ }^{-1}$ of water is estimated, which indicates a negative change in storage of $13.86 \mathrm{hm}^{3}$ year $^{-1}$ (CONAGUA, 2015).

Main mineralized zones within the area are, from north to south: Buenavista del Cobre (Cu-Mo) in Cananea, El Gachi ( $\mathrm{Pb}-\mathrm{Zn}$ ) east of Arizpe, Santa Elena ( $\mathrm{Au}$ ) east of Banámichi, San Felipe de Jesus (Cu, $\mathrm{Pb}, \mathrm{Zn}$ and $\mathrm{Au}$ ), El Jaralito (W), and Washington ( $\mathrm{Cu}, \mathrm{W}$, and $\mathrm{Mo}$ ) to the west and east of Baviácora, respectively (Archundia et al., 2021). The area has tree active mines, Buenavista del Cobre, El Jaralito, and Santa Elena and 15 known abandoned mines (Guzmán et al., 2019).

The study area has a long history of mining activity. Thus, mine tailings, abandoned mines, active mines, as well as natural mineralization (Calmus et al., 2018; Del Rio-Salas et al., 2019; Guzmán et al., 2019) occurs in the region. The main mining operations correspond, from north to south, to the El Gachi mine $(\mathrm{Pb}-\mathrm{Zn})$ located east of Arizpe, the Santa Elena mine ( $\mathrm{Au}$ ) localized east of Banámichi, the San Felipe mine ( $\mathrm{Cu}, \mathrm{Pb}, \mathrm{Zn}$ and $\mathrm{Au})$, as well as, El Jaralito $(\mathrm{W})$ and the Washington mine ( $\mathrm{Cu}, \mathrm{W}$ and $\mathrm{Mo})$ situated west and east of Baviácora, respectively (Calmus et al., 2018). The El Gachi mine is currently inactive and corresponds to a distal replacement deposit related to a porphyry copper-like environment, lodged in sediments that correspond to the Early Cretaceous (Zuñiga-Hernández, 2010). The Santa Elena mine is the largest active mining site within the study area; it is considered of hydrothermal origin, the elements with the highest abundance are $\mathrm{Au}, \mathrm{Ag}, \mathrm{Zn}$ and $\mathrm{Pb}$ (Calmus et al., 2018). The San Felipe mining area is 
currently abandoned; it has several mineral deposits in the form of hydrothermal veins. The main extraction minerals were pyrite, chalcopyrite, galena and sphalerite. This area is also characterized by the presence of abandoned tailings (Del Rio-Salas et al., 2019). The Jaralito mine is of the skarn-type deposit and has records of pegmatite bodies with W-Be mineralization (Roldán-Quintana, 1991). The Washington mine is currently abandoned and corresponds to a breccia sedimentary rock located in a sequence of volcanic rocks of the Tarahumara Formation (Simmons and Sawkings, 1983; Zuñiga-Hernández, 2010).

There are records of metal contamination in the region since the 1980s (Gomez-Alvarez et al., 1990). Del Rio-Salas et al., (2019) observed that efflorescence minerals and mine tailings from the area have a high toxicity and potential to affect the quality of water (groundwater and surficial) in the region. The mobility and accessibility of some potentially toxic elements ( $\mathrm{Zn}, \mathrm{Pb}$, and $\mathrm{As})$ were investigated from the mining tailings of San Felipe de Jesús and adjacent agricultural soils located within the aquifer. Zinc was mainly recovered from labile fractions in oxide-rich tailings $(\sim 60 \%)$ and in a lower amount from sulfide-rich tailings $(\sim 30 \%)$. The percentage of mobile fractions (sum of water-soluble, exchangeable, and bound to carbonate fractions) in agricultural soils was as follows: $\mathrm{Zn} \sim 60 \%, \mathrm{~Pb} \sim 15 \%$, and As 70\% (LoredoPortales et al., 2020). Recently, Archundia et al., (2021) documented point source locations of potentially toxic elements producing contamination of the Rio Sonora basin where the studied aquifer is located.

\subsubsection{Geology}

A variety of igneous, sedimentary and metamorphic rocks emerge in the study area, ranging from the Precambrian to recent times. The oldest are intrusive igneous and metamorphic rocks that emerge in the western part of Banámichi and Huépac (Fig. 1). The metamorphic rocks correspond to schists and gneisses of the Lower Proterozoic. The intrusive igneous rocks correspond to granites of the Cananea (north of the study area) granite complex, with an age of 1.44 G.a (Anderson and Silver, 1977; Calmus et al., 2018) from the Middle Proterozoic. The Paleozoic is characterized by quartzites from the Cambrian at the municipalities of Banámichi and Huépac (Fig. 1), and intercalations of limestone and sandstones with a certain degree of metamorphism that emerge at the municipalities of Hermosillo, Ures and Baviácora (Fig. 1), corresponding to the Carboniferous-Permian. This set is known as metamorphic Paleozoic units, which occur on the western edge of the study area in the direction of the Sonora River channel. The Mesozoic is present in outcrops on the eastern and western edges of the study area. The oldest rocks of this period correspond to intercalations of rhyolite-sandstone, sandstone-siltstone and shale-sandstone located west of the Municipality of Banámichi and southwest of the Municipality of Arizpe (Fig. 1). The Cretaceous is characterized by a volcanic-sedimentary environment with outcrops of Andesite-Sandstone and Andesite-Andesite Toba (Calmus et al., 2018; Coney and Reynolds, 1977). The end of the Cretaceous period is represented by plutonic rocks (granites and granodiorites) which are distributed in the area, mainly in the central area, at Ures, Baviácora and Aconchi (Fig. 1). Cenozoic rocks cover the greatest extension in the study area. The Cenozoic is characterized by a magmatic environment, thus volcanic rocks such as the Andesite and Basalt Rhyolites are present. In addition, pyroclastic emissions are present in the northern part, the edges of the study area and at the municipalities of Ures. 
The Quaternary is defined by the presence of alluvial and fluvial deposits located in the channels of the rivers, streams and flood plains (CONAGUA, 2015).

\subsection{Evaluation of the intrinsic aquifer vulnerability}

The DRASTIC method was used to determine the intrinsic aquifer vulnerability at the Rio Sonora aquifer. The model was developed by the Environmental Protection Agency (EPA) in 1987 to evaluate the potential for groundwater contamination (Aller, 1987). Today it is the most frequently used method to asses aquifer vulnerability at porous media (Al-Mallah and Al-Qurnawi, 2018; Barbulescu, 2020; Jia et al., 2019; Kozłowski and Sojka, 2019; Lappas, and Matiatos, 2014). It has been already used to asses groundwater vulnerability to pollution at mining areas (Bukowski et al., 2006; Haque et al., 2018; Tiwari et al., 2016). The method is based on seven hydrogeological parameters: Groundwater depth (D), Recharge $(R)$, Aquifer media (A), Soil (S), Topography (T), Impact of the vadose zone (I) and Hydraulic Conductivity (C). It is based on four major assumptions: $i)$ the contaminant is introduced at the ground surface; ii) the contaminant is flushed into the groundwater by precipitation; iii) the contaminant has the mobility of water; and iv) the area evaluated is 40 ha or larger (Aller, 1987). The method produces index numbers derived from the rating $(r)$ and weights $(w)$ assigned to each parameter, the higher the DRASTIC index, the greater is the groundwater pollution potential. The DRASTIC index (D) was calculated as follows:

$$
D=D_{r} D_{w}+R_{r} R_{w}+A_{r} A_{w}+S_{r} S_{w}+T_{r} T_{w}+I_{r} I_{w}+C_{r} C_{w}
$$

The DRASTIC index varies from 23 to 230. The categories to interpret the DRASTIC index are: very low vulnerability (23-64), low vulnerability (64-100), medium vulnerability (106-147), high vulnerability (147188), very high vulnerability (188-230).

The maps corresponding to the seven parameters were constructed with available hydrogeological data in the GIS-ArcView software. The depth to groundwater was estimated from 2014 piezometric data from 168 wells. Piezometric data was obtained from the Water National Commission (CONAGUA) from Wells located along the Sonora River. For the areas where there was no data, it was interpolated using the Inverse distance weighted interpolation based on existing values. The recharge was estimated from daily precipitation data (1925 to 2012) obtained from CONAGUA weather stations at Arizpe, Sinoquipe, Banámichi, Huépac, Aconchi, Mazocahui, Ures and Topahue (Fig. 1) using the formula:

$\mathrm{RN}=\mathrm{P}-\mathrm{Er}(\mathrm{mm} /$ year $)$

Where $\mathrm{RN}$ is the net recharge $(\mathrm{mm}), \mathrm{P}$ is the mean annual precipitation $(\mathrm{mm})$ and $\mathrm{Er}$ is the real annual evapotranspiration (mm). The Er was estimated using the Turc method (Belmonte-Jiménez et al., 2005).

Recharge data was interpolated to the whole study area using the Inverse distance weighting (IDW) method. The aquifer media and the Impact of the vadose zone thematic maps were constructed based on existing geological maps from the Sonora Water Commission; data was reclassified according to the types of lithology recommended by Aller, (1987). The soil media thematic map was constructed based on the World Soil Information (2017) data base; data was reclassified according to the soil types 
recommended by Aller, (1987). The topography data was generated in ArcGis from the Continuum of Mexican Elevations of the Mexican National Institute of Statistic and Geography (INEGI, 2013). Used hydraulic conductivity values were obtained from the Global Hydrogeology Maps (GLHYMPS) of permeability and porosity (Gleeson et al., 2014) applying the formula:

$$
K=\frac{k \rho g}{\mu}
$$

Where $\mathrm{K}(\mathrm{m} / \mathrm{s})$ is the hydraulic conductivity that depends on the viscosity and density of the fluid, $k\left(\mathrm{~m}^{2}\right)$ is the permeability, $\rho\left(\mathrm{kg} \mathrm{m}^{3}\right)$ is the density of the fluid (water $\left.=999.97 \mathrm{~kg} \mathrm{~m}^{3}\right), g\left(\mathrm{~m} \mathrm{~s}^{2}\right)$ is the acceleration due to gravity $\left(9.8 \mathrm{~m} \mathrm{~s}^{2}\right)$ and $\mu\left(\mathrm{kg} \mathrm{m}^{\star} \mathrm{s}^{-1}\right)$ is the viscosity of the fluid (water $=0.001$ ).

\subsection{Evaluation of the aquifer vulnerability to metal pollution at mining areas: DRASTIC + Lu}

A modification to the DRASTIC method was carried out by adding a land use parameter ( $\mathrm{Lu}$ ) including the location of possible metals sources (known mining areas, mining wastes and mineralized areas) detected using remote sensing methods. The detection of the possible sources of metals was performed following the supervised classification method based on the NDVI values of known mining areas, mining wastes and mineralized areas of the study site.

\subsubsection{Detecting possible sources of metallic contamination by remote sensing}

In this work, remote sensing was used in order to locate potential sources of metals related to mining activity (mining tailings, active/inactive mines) or areas with exposed natural geochemical anomalies in an efficient and economical way covering large areas affected by mining activities. Freely-available satellite images were obtained from SENTINEL 2 at a resolution of $10 \mathrm{~m}$; they were processed with the free access Quantum GIS software (QGIS Development Team, 2019). We used two May 22, 2019 images covering the study area presenting $0.1 \%$ cloudiness, in a UTM / WGS84 projection (Universal Transversal Mercator) of $100 \mathrm{~km} \times 100 \mathrm{~km}$. We selected the bands 2, 3, 4 and 8 with a spatial resolution of 10 meters. They were processed using QGIS and the Semi-Automatic Classification Plugin (SCP) to carry out the atmospheric correction using the dark pixel subtraction method (DOS1). Selected bands were combined to produce a mosaic dataset using the Mosaic Raster Layer de SAGA (System for Automated Geoscientific Analyses) by the Nearest Neighbor method.

Spectral characteristics of tailings and other background features (water bodies, vegetation and bare soil) were studied by the photointerpretation of 5 points (selected manually) of each class located inside the study area.

NDVI was employed to distinguishing the boundaries of vegetated terrain from tailings impoundments, mining sites and areas with exposed natural geochemical anomalies, which are characterized by negative 
pixel values. The NDVI assigns values in a range from -1 to 1 , negative values and close to -1 correspond to bodies of water and negative values close to zero correspond to areas with bare or rocky soil, sand or snow (Saravanan et al., 2019); thus, we focus on negative values close to 0. NDVI was calculated as follows:

$$
\mathrm{NDVI}=\frac{N I R-R e d}{N I R+R e d}
$$

To increase the precision of the method and effectively distinguish from bare soils and built-up areas, the optimal NDVI threshold was defined based on the minimum and maximum NDVI values exhibited by 5 training fields (areas of known identity) including mining wastes and active/inactive mines of the study site (Table 1).

Table 1

Training fields.

\begin{tabular}{|lll|}
\hline Site & Description & Coordinates UTM $(X, Y)$ \\
\hline San Felipe de Jesús & Mine tailings & $572710.25,3302388.74$ \\
\hline Santa Elena Mine & Active mine, mine tailings & $580748.16,3321310.64$ \\
\hline Santa Rosa & Mine tailings & $568697.7,3306965.56$ \\
\hline El Carmen & Mine tailings & $581333.92,3341470.91$ \\
\hline El Realito & Processing plant & $580574.86,3284836.18$ \\
\hline
\end{tabular}

The polygons generated as described above were subsequently verified and validated manually to ensure the selection of polygons corresponding to the class "possible sources of metallic contamination" counting for mining tailings, active/inactive mines and areas with exposed natural geochemical anomalies. We considered areas of at least $400 \mathrm{~m}^{2}$ or four pixels. Detection was validated by comparing visually the identified polygons to existing information (Zeng et al., 2017).

\subsubsection{DRASTIC + Lu}

The DRASTIC method was modified by introducing a Land Use (Lu) parameter ( $100 \mathrm{~m}^{2}$ resolution) in which the potential sources of metals (identified using remote sensing) were integrated as one class type. The original Lu data was obtained from the Mexican National Institute of Statistic and Geography (INEGI, 2016). Ratings were defined based on the potential to lead to metallic contamination of each class. Assigned ratings and the Lu parameter weight are shown in Table 2. Most of the study area is covered by secondary vegetation, grasslands, forest and scrub, with assigned rating of 1 , considered with little influence on metal pollution. Ratings of 5, 6 and 7 were assigned to areas with human activity. Ratings to agriculture activity depends on irrigation type as the water infiltration promotes the mobility of contaminants to the aquifer. Finally, a rating of 10 was assigned to the mining and mineralized areas due to their polluting potential. 
Table 2

Ratings of considered land use types.

\begin{tabular}{|c|c|c|}
\hline \multicolumn{3}{|c|}{ Land use (Lu) } \\
\hline Class & Description & Rating \\
\hline $\begin{array}{l}\text { Possible } \\
\text { source of } \\
\text { metals }\end{array}$ & Mining areas, mining wastes and mineralized areas & 10 \\
\hline $\begin{array}{l}\text { Rainfed } \\
\text { agriculture }\end{array}$ & Annual and semi-permanent agriculture & 6 \\
\hline $\begin{array}{l}\text { Irrigated } \\
\text { Agriculture }\end{array}$ & Annual irrigation and semi-permanent irrigation agriculture & 7 \\
\hline Urban & Urban & 5 \\
\hline Water body & Water body & 1 \\
\hline Pastureland & Cultivated Grassland, Induced Grassland, Natural Grassland & 1 \\
\hline Forest & Oak and Prosopis scrub & 1 \\
\hline Scrub & Microphyllous desert scrub, thorn, subtropical scrub and Prosopis scrub & 1 \\
\hline $\begin{array}{l}\text { Secondary } \\
\text { vegetation }\end{array}$ & $\begin{array}{l}\text { Shrubby Secondary Vegetation of oak Forest, Shrubby Secondary } \\
\text { Vegetation of Sarcocaule Scrub, Shrubby Secondary Vegetation of } \\
\text { Subtropical Prosopis and Shrubby Secondary Vegetation of Xerophilous } \\
\text { Prosopis }\end{array}$ & 1 \\
\hline Wheight & & 5 \\
\hline
\end{tabular}

The DRASTIC + Lu index was calculated as follows:

$$
D_{L u}=D_{r} D_{w}+R_{r} R_{w}+A_{r} A_{w}+S_{r} S_{w}+T_{r} T_{w}+I_{r} I_{w}+C_{r} C_{w}+L u_{r} L u_{w}
$$

In order to compare both methods, the results obtained in the original and modified DRASTIC method were normalized to scale from 0 to 100 . The index was divided into five categories: very low vulnerability (<20), low vulnerability (20-40), medium vulnerability (40-60), high vulnerability $(60-80)$, very high vulnerability (80-100).

\subsection{Validation}

\subsubsection{Map removal sensitivity analysis of the DRASTIC + Lu}

To investigate the effects of adding the Lu parameter on the vulnerability map, we performed the map removal sensitivity analysis which show the sensitivity of the vulnerability map by removing one or more parameters from the analysis. It is computed in the following way (Babiker et al., 2005):

$$
S=\left(\frac{V}{N}-\frac{V^{\prime}}{\mathrm{n}} / V\right) * 100
$$


where $\mathrm{S}$ is the sensitivity measure expressed in terms of variation index, $\mathrm{V}$ and $\mathrm{V}^{\prime}$ are the unperturbed (DRASTIC) and the perturbed (DRASTIC + Lu) vulnerability indices respectively, and $\mathrm{N}$ and $\mathrm{n}$ are the number of data layers used to compute $V$ and $V^{\prime}$.

\subsubsection{Correlation between groundwater metal concentrations and calculated indexes}

The groundwater metal concentrations from governmental surveys (public data) carried out by the National Water Commission (CONAGUA) were used to associate and correlate the metal pollution in the groundwater to the vulnerability indexes obtained with the original DRASTIC and modified methods. Used data is freely available at http://www.fideicomisoriosonora.gob.mx/fideicomiso.html and corresponds to $\mathrm{Al}, \mathrm{Cu}, \mathrm{Zn}, \mathrm{Mn}$ y Fe average concentrations (measurements between august and september $2014 \mathrm{in} \mathrm{mg}$ $\mathrm{L}^{-1}$ ) from 28 wells located following the Sonora River (Figure 1). We calculated the spearman correlation due to the non-normality of data.

\section{Results And Discussion}

\subsection{Assessment of the intrinsic aquifer vulnerability with DRASTIC}

The seven thematic maps representing the parameters of the DRASTIC method were prepared using existing input data based on GIS.

Groundwater Depth (D) According to the input data obtained from CONAGUA, the parameter varies between 0 and $23 \mathrm{~m}$. The ratings assigned according to the DRASTIC method (Aller, 1987) ranged between 3 and 10 (Fig. 2). Input data was obtained from points located following the Sonora River from north to south of the studied aquifer and not well distributed on the study area; thus, some imprecision could be attributed. Nevertheless it is largely accepted that in the area groundwater depth ranges from 1 to $30 \mathrm{~m}$, increasing in the direction of the Sonora River, which is shaped by the basement topography underlying alluvial and fluvial deposits, as well as by the narrowing of the Rio Sonora that lifter the water level, causing it to emerge (Archundia et al., 2021; CONAGUA, 2015).

Recharge $(R)$ This parameter was calculated based on precipitation input data from 8 climatological stations dating between 1925 - 2012 and IDW interpolation. Some imprecision could be expected as climatological stations were located following the Sonora River, where the municipalities of the area are located. Recharge values of 0 to $51 \mathrm{~mm}$ were obtained in the central part of the southern portion, values between 51 and $102 \mathrm{~mm}$ were obtained on the margins of the southern portion and values from 102 to $178 \mathrm{~mm}$ were found in the upper and more extensive part. The ratings assigned according to the DRASTIC method (Aller, 1987) were between 1 and 9 (Fig. 3).

Aquifer media (A) The lithology of the study area is mainly of igneous and metamorphic rocks, which are poorly permeable and non-porous unless fractured (rating 3). Sequences of sedimentary rocks, such as 
sandstones and shales, appear sporadically within the study area (rating 6). In some areas located near of San Felipe de Jesús and Arizpe conglomerates and basalt occur, and a high rating was assigned (7 and 8 respectively) as they present interconnected pores and fractures. Conglomerate are also common in the surrounding of the Sonora River channel. The alluvium (rating 10) is mainly located in the Sonora streambed and its tributaries (Fig. 4).

Soil (S) According to the World Soil Information (2017), four soil texture types occur in the study area (Fig. 5). Soils with a large fraction of clay occur surrounding the Sonora River (rating 3). Sandy-clay soils are present in the lower proportions and especially in the middle and southern portion of the study area (rating 4). Clay-loam soils are located on high altitudinal areas (rating 5). Sandy clay loam soils are found in the highest altitudinal areas where igneous and metamorphic rocks are located (rating 6) (Fig. 5). It is important to note that the World Soil Information combines existing regional and national updates of soil information worldwide so it may lack precision at a local scale.

Topography $(T)$ Most of the study area has slope values greater than $18 \%$, near the Sonora River and at the southeastern part very low and null slope values occur. Rating varies between 1 and 10 (Figure 6).

Impact of the vadose zone (I) Igneous and metamorphic rocks with reduced permeability are located at the eastern and western parts of the study area (rating 4). Sedimentary and permeable rocks occur from north to south following the Sonora River channel (rating 6). Basaltic rocks, which could show significant porosity and permeability, are in spots at the north and the center (rating 7). Finally, the alluvium, highly permeable, is found from north to south associated to the Sonora River channel (rating 8) (Fig. 7).

Hydraulic Conductivity (C) Hydraulic conductivity values were obtained from high resolution global lithology existing maps; thus some imprecision could be expected. Most of the study area present values between 0 and $28.55 \mathrm{~cm}$ day $^{-1}$. Some spots which coincide with the presence of carbonate rocks show values greater than $81 \mathrm{~cm} \mathrm{day}^{-1}$, corresponding to an average conductivity in free aquifers (Fig. 8). The area with the lowest hydraulic conductivity (rating 1) corresponds to the igneous body known as the Aconchi batholith.

DRASTIC index. The DRASTIC vulnerability index was computed overlaying the seven hydro-geological parameter maps presented above: values range from 64 to 171. The groundwater vulnerability of the Rio Sonora aquifer fluctuates from low, at some places in the center and the south, to high (Fig. 9). The results of this study show that $23.61 \%$ of the study area has low pollution potential, $72.95 \%$ has moderate pollution potential and $3.43 \%$ has high pollution potential. The distribution of the Rio Sonora aquifer intrinsic vulnerability is mainly conditioned by the lithology and the impact of the vadose zone. The yellow and green colors correspond to areas with igneous rocks, which were classified as low permeable rocks. In the center of the study area, the orange color corresponds to the conglomerate rocks and the red color represents the channel of the Sonora River where the alluvium is found. In the southeast zone there are also colorations that indicate high vulnerability, most likely due to the lithology (alluvial 
deposits) and a low slope. This is of great importance since most of the drinking water supply wells are located near the channel of the Sonora River of high vulnerability.

\subsection{Evaluation of the Rio Sonora aquifer vulnerability to metal pollution (DRASTIC + Lu index)}

The DRASTIC method was modified by introducing an extra parameter considering the Land Use (Lu) in which the potential sources of metals, identified by remote sensing, were incorporated.

\subsubsection{Detection of possible sources of metallic contamination by remote sensing}

Figure 10 show the averaged spectral characteristics of tailings, water bodies, vegetation and bare soil in the study site. When comparing spectral signatures, we notice the different behaviors of background features, which validate the use of remote sensing for the identification of possible sources of metallic contamination as mine tailings. The group of "Water body" and "Vegetation" show typical behaviors. The reflectance value of a water body decreases as the wavelength increases, due to low reflection in the near infrared. Vegetation presents a peak in the infrared spectrum. Both the Mine Tailings and the Bare Soil groups present high reflectance values in the studied bands. However, the first tend to have a reflectance peak in the red band and higher reflectance values.

The NDVI values threshold defined based on considered training fields was between -0.2504 and 0.1946 it allowed detecting non-vegetated areas including considered training fields (Fig. 11).

Base on defined NDVI threshold and after the manual filtration, 60 areas representing the possible sources of metallic pollution were located (Fig. 12 and SI.1). Among the most important detected points are the tailings dam of the Santa Elena mine and the Santa Elena mine itself, which are found $4.5 \mathrm{~km}$ from the Banámichi municipality. Both conform the largest detected point with approximately 779,297 $\mathrm{m}^{2}$. The mining tailings of San Felipe de Jesús have $33,022 \mathrm{~m}^{2}$ and are located $670 \mathrm{~m}$ southeast of the San Felipe of Jesus municipality in front of an agriculture area that is directly affecting it as recently observed by Loredo-Portales et al., (2020). Natural mineralized areas were located northwest of Banámichi near the Zatecona abandoned mine, east of the Aurora town near El Aguilillo abandoned mine. Other identified areas correspond to excavation areas located close to mines or to mines themselves. Generally, identified areas are distributed in parallel to the Sonora River and in the highest elevation zones. It should be mentioned that our results only estimate the extent of mineralized areas because they could be masked by alluvial deposits, vegetation or landslides. When comparing with existing information of the Mexican Geological Survey (Servicio Geológico Mexicano, SGM), the number of new identified mining areas is notable southeast of Ures. All mining wastes identified by the Mexican National Center for Disaster Prevention (CENAPRED, 2017), as well as, all considered training fields were identified through the proposed methodology.

\subsubsection{DRASTIC + Lu index}

Page 12/33 
Identified possible sources of metallic pollution were integrated to the Land use information of the Mexican National Institute of Statistic and Geography (INEGI, 2016). The DRASTIC + Lu index was computed as described in the methodology section. Figure 13 shows the DRASTIC+Lu index which varied from 69 to 201. The study area presents moderate and high vulnerability values, according to the vulnerability scale proposed by Aller (1987). The elevated areas located between Mazocahui and Ures (south of the study area) display low vulnerability values (64-106), representing the $14.11 \%$ of the study area. Moderate vulnerability values between 106 and 146, correspond to igneous rocks with elevated slope, representing $75.78 \%$ of the area. Areas of high vulnerability (147-188) are located following the Sonora River and correspond to conglomerate rocks and represents $9.53 \%$ of the zone. Areas with very high vulnerability (188-230) correspond to the Sonora riverbed, representing the $0.58 \%$.

\subsection{Comparison between calculated indexes.}

Normalized vulnerability maps (on a scale of 1 to 100) obtained by the DRASTIC and DRASTIC+Lu methods are shown in Figure 14. We notice that in both maps the areas of lower vulnerability are in upper parts, corresponding to igneous rocks and areas with pronounced slope. Greatest vulnerability values (dark red color) correspond to conglomerate rocks, the presence of agricultural areas and low slope. The mining and mineralized areas are almost imperceptible on the scale of the maps, but they increased the vulnerability at a local level. Comparing both maps, a general decrease in vulnerability can be observed in the DRASTIC + Lu map. The area of very high vulnerability (80-100) decreased by $15 \%$, the extent of high vulnerability (60-80) decreased by $81.3 \%$, the zone of medium vulnerability increased slightly $(8.4 \%)$, the area of low vulnerability increased in $94 \%$ and the area of very low vulnerability increased by $154.9 \%$. This analysis allowed the identification of high vulnerability areas on which protection efforts need to be focused and to localize small sites with strong negative local effects.

\subsection{Validation of the proposed DRASTIC + Lu method}

The map removal sensitivity analysis was preferred because it tests the sensitivity of operations between map layers (Thapa, 2018) helping to evaluate its influence on the vulnerability assessment. Table 3 show statistical calculation of results. The DRASTIC + Lu vulnerability index computed for the study area is least sensitive to the Aquifer media (average value 0.82 ) and highly sensitive to the Groundwater depth (average value 3.75). Regarding the effect of GIS identified sources of metallic pollution included on the Lu parameter, the influence of the Lu cover is high in our study area showing the third highest value. This validates the performed modification to the DRASTIC method and demonstrates the importance of considering the sources of metallic contaminants when assessing the groundwater vulnerability in a mining context. 
Table 3

DRASTIC + Lu map removal sensitivity analysis.

\begin{tabular}{|lllll|}
\hline Removed factor & Min & Max & Mean & Std. Deviation \\
\hline D & 0 & 5.27 & 3.75 & 0.7 \\
\hline R & 0 & 2.71 & 1.08 & 0.47 \\
\hline A & 0 & 2.27 & 0.82 & 0.34 \\
\hline S & 0.02 & 3.2 & 1.48 & 0.61 \\
\hline T & 0 & 3.25 & 1.73 & 0.46 \\
\hline I & 0.02 & 3.7 & 1.45 & 0.71 \\
\hline C & 0.13 & 3.02 & 1.28 & 0.37 \\
\hline L & 0.1 & 4.46 & 1.51 & 0.3 \\
\hline
\end{tabular}

Observed groundwater metal concentrations from governmental surveys (public data) did not show a significant correlation ( $p$ value $>0.1$ for all tested metals) with the vulnerability zones identified using DRASTIC and DRASTIC + Lu methods. This observation suggests that sources of observed metal concentrations in groundwater could be of geogenic origin rather than superficial. Nevertheless, the lack of a significant correlation could also be associated to the fact that metal concentrations were determined after a mining spill event that occurred at the Buenavista del Cobre mine located north and outside of the study area. Thus, metal concentrations may be related to horizontal transport process within the aquifer. Furthermore, metals can show high reactivity with some vadose zone and aquifer components not considered here, thus affecting the correlation between considered metal concentrations and computed vulnerability values. There is evidence of the stabilizing power of the soils of the study area. Rivera-Uria et al., (2018) observed that soil carbonate content has an impact on the neutralization of acid solutions causing the immobilization of metals. Recently, Archundia et al., (2021) detected no metallic ground water pollution at the study area, possibly indicating that no entry of metallic pollutants from the surface is occurring. Based on this, results produced on this study can be used for the design of protective measures and land use plans that effectively prevents groundwater pollution in detected highly vulnerable areas.

To better understand the metal (and others) pollutants fate and dynamics in the study area it is important to perform studies on the prediction of groundwater flow, superficial soil and subsurface (vadose zone) properties and reactivity against metals. In that sense and in order to improve the vulnerability assessment it is suggested to characterize soil types and properties as well as ground water depth at a local scale.

\section{Conclusion}


The proposed remote sensing methodology allowed to locate 60 possible sources of metallic contamination, corresponding to mining tailings, open-pit wastes, areas with exposed natural mineralization and areas with current mining activity. Within the identified sources, only three correspond to exposed natural mineralization areas, possibly indicating that the method might not be sensitive enough. The use of higher resolution satellite images could improve the precision to locate them but significantly increasing the costs of the method.

The Sonora River channel has the higher vulnerability in both calculated vulnerability indices (DRASTIC and DRASTIC+Lu) indicating that the aquatic resources of the populations located within the study area are threatened. To improve the precision of the modified method results, an effort in the characterization of the water depth and soil type information at the local scale is needed. With the application of the modified DRASTIC index and, in comparison with the results obtained with the traditional DRASTIC index, a decrease in vulnerability was observed, mainly in conglomerate rocks and higher elevation areas located parallel to the Sonora River channel. This general decrease in vulnerability coupled with a local increase of vulnerability where possible sources of metals are located, facilitated to highlight highly vulnerable areas which is relevant to better protect the studied aquifer.

\section{Declarations}

\section{Acknowledgments}

This work was supported by Programa de Apoyo a Proyectos de Investigación e Innovación Tecnológica (PAPIIT) - Universidad Nacional Autónoma de México (UNAM): UNAM-PAPIIT IN212720.

\section{Statements and Declarations}

This work was supported by Programa de Apoyo a Proyectos de Investigación e Innovación Tecnológica (PAPIIT) - Universidad Nacional Autónoma de México (UNAM): UNAM-PAPIIT IN212720.

\section{References}

1. Abdullah TO, Ali SS, Al-Ansari NA, Knutsson S (2015) Groundwater Vulnerability Mapping Using Lineament Density on Standard DRASTIC Model: Case Study in Halabja Saidsadiq Basin, Kurdistan Region. Iraq Engineering 07:644-667. https://doi.org/10.4236/eng.2015.710057

2. Abu-Bakr HA, el-Aziz (2020) Groundwater vulnerability assessment in different types of aquifers. Agric Water Manag 240:106275. https://doi.org/10.1016/j.agwat.2020.106275

3. Aller L (1987) DRASTIC: A STANDARDIZED SYSTEM FOR EVALUATING GROUND WATER POLLUTION POTENTIAL USING HYDROGEOLOGIC SETTINGS 641

4. Al-Mallah IAR, Al-Qurnawi WS (2018) Intrinsic vulnerability assessment for the Quaternary aquifer in Baghdad area using DRASTIC model. Appl Water Sci 8:139. https://doi.org/10.1007/s13201-0180747-1 
5. Anderson TH, Silver LT (1977) Geochronometric and stratigraphic outlines of the Precambrian rocks of northwestern Mexico, vol 9. Geological Society of America Abstracts with Programs

6. Archundia D, Prado-Pano B, González-Méndez B, Loredo-Portales R, Molina-Freaner F (2021) Water resources affected by potentially toxic elements in an area under current and historical mining in northwestern Mexico. Environ Monit Assess 193:236. https://doi.org/10.1007/s10661-021-08998-z

7. Aydi A (2018) Evaluation of groundwater vulnerability to pollution using a GIS-based multi-criteria decision analysis.Groundw. Sustain. Dev.8

8. Babiker IS, Mohamed MAA, Hiyama T, Kato K (2005) A GIS-based DRASTIC model for assessing aquifer vulnerability in Kakamigahara Heights, Gifu Prefecture, central Japan. Sci Total Environ 345:127-140. https://doi.org/10.1016/j.scitotenv.2004.11.005

9. Balaniuk R, Isupova O, Reece S (2020) Mining and Tailings Dam Detection In Satellite Imagery Using Deep Learning. ArXiv200701076 Cs Eess

10. Barbulescu A (2020) Assessing Groundwater Vulnerability: DRASTIC and DRASTIC-Like Methods: A Review. Water 12:1356. https://doi.org/10.3390/w12051356

11. Belmonte-Jiménez SI, Campos-Enríquez JO, Alatorre-Zamora MA (2005) Vulnerability to contamination of the Zaachila aquifer, Oaxaca, Mexico. Geofísica Int 44:283-300. https://doi.org/10.22201/igeof.00167169p.2005.44.3.200

12. Buczyńska A (2020) Remote sensing and GIS technologies in land reclamation and landscape planning processes on post-mining areas in the Polish and world literature. Presented at the 2 nd International Conference On Materials Engineering \& Science (Iconmeas 2019), Baghdad, Iraq, p. 040002. https://doi.org/10.1063/5.0000009

13. Bukowski P, Bromek T, Augustyniak I (2006) Using the DRASTIC System to Assess the Vulnerability of Ground Water to Pollution in Mined Areas of the Upper Silesian Coal Basin. Mine Water Environ 25:15-22. https://doi.org/10.1007/s10230-006-0104-8

14. Calmus T, Valencia-Moreno M, Río-Salas D, Ochoa-Landín R, Mendivil-Quijada L, H (2018) A multielemental study to establish the natural background and geochemical anomalies in rocks from the Sonora river upper basin, NW Mexico. Rev Mex Cienc Geológicas 35:158-167. https://doi.org/10.22201/cgeo.20072902e.2018.2.605

15. CENAPRED (2017) Peligro por residuos mineros

16. CONAGUA (2015) Actualizacion de la disponibilidad media anual e agua en el acuifero Rio Sonora (2624)

17. Coney PJ, Reynolds SJ (1977) Cordilleran Benioff zones. Nature 270:403-406

18. Connette KJL, Connette G, Bernd A, Phyo P, Aung KH, Tun YL, Thein ZM, Horning N, Leimgruber P, Songer M (2016) Assessment of Mining Extent and Expansion in Myanmar Based on FreelyAvailable Satellite Imagery 14

19. Del Rio-Salas R, Ayala-Ramírez Y, Loredo-Portales R, Romero F, Molina-Freaner F, Minjarez-Osorio C, Pi-Puig T, Ochoa-Landín L, Moreno-Rodríguez V (2019) Mineralogy and Geochemistry of Rural Road 
Dust and Nearby Mine Tailings: A Case of Ignored Pollution Hazard from an Abandoned Mining Site in Semi-arid Zone. Nat Resour Res. https://doi.org/10.1007/s11053-019-09472-x

20. Firozjaei MK, Sedighi A, Firozjaei HK, Kiavarz M, Homaee M, Arsanjani JJ, Makki M, Naimi B, Alavipanah SK (2021) A historical and future impact assessment of mining activities on surface biophysical characteristics change: A remote sensing-based approach. Ecol Indic 122:107264. https://doi.org/10.1016/j.ecolind.2020.107264

21. Gleeson T, Moosdorf N, Hartmann J, van Beek LPH (2014) A glimpse beneath earth's surface: GLobal HYdrogeology MaPS (GLHYMPS) of permeability and porosity. Geophys Res Lett 41:3891-3898. https://doi.org/10.1002/2014GL059856

22. Gogu RC, Dassargues A (2000) Current trends and future challenges in groundwater vulnerability assessment using overlay and index methods. Environ Geol 39:549-559. https://doi.org/10.1007/s002540050466

23. Gomez-Alvarez A, Yocupicio-Anaya MTJ, Ortega-Romero P (1990) Niveles y distribucion de metales pesados en el rio Sonora y su afluente el rio Bacanuchi. Sonora, Mexico Ecologica 1:10-20

24. Guzmán HM, Gómez-Álvarez A, Valenzuela-García JL, Encinas-Romero MA, Villalba-Atondo Al, Encinas-Soto KK (2019) Assessment of the impact on sediment quality from abandoned artisanal mine runoffs in a semi-arid environment (the Sonora River basin-Northwestern Mexico). Environ Earth Sci 78. https://doi.org/10.1007/s12665-019-8131-5

25. Hao L, Zhang Z, Yang X (2019) Mine tailing extraction indexes and model using remote-sensing images in southeast Hubei Province. Environ Earth Sci 78:493. https://doi.org/10.1007/s12665-0198439-1

26. Haque E, Reza S, Ahmed R (2018) Assessing the vulnerability of groundwater due to open pit coal mining using DRASTIC model: a case study of Phulbari Coal Mine. Bangladesh Geosci J 22:359371. https://doi.org/10.1007/s12303-017-0054-0

27. INEGI (2016) Uso del suelo y vegetación, escala 1:250000, serie VI\&\#8221

28. INEGI (2013) Continuo de Elevaciones Mexicano (CEM)

29. Jia Z, Bian J, Wang Y, Wan H, Sun X, Li Q (2019) Assessment and validation of groundwater vulnerability to nitrate in porous aquifers based on a DRASTIC method modified by projection pursuit dynamic clustering model. J Contam Hydrol 226:103522.

https://doi.org/10.1016/j.jconhyd.2019.103522

30. Jr RH, Viero AP (2006) Groundwater vulnerability assessment in coastal plain of Rio Grande do Sul State, Brazil, using drastic and adsorption capacity of soils 1

31. Khosravi V, Ardejani FD, Gholizadeh A, Saberioon M (2021) Satellite Imagery for Monitoring and Mapping Soil Chromium Pollution in a Mine Waste Dump. Remote Sens 13:1277. https://doi.org/10.3390/rs13071277

32. Kozłowski M, Sojka M (2019) Applying a Modified DRASTIC Model to AssessGroundwater Vulnerability to Pollution:A Case Study in Central Poland. Pol J Environ Stud 28:1223-1231. https://doi.org/10.15244/pjoes/84772 
33. Lappas I, Matiatos I (2014) Groundwater vulnerability assessment mapping in Argos alluvial basin using GIS - based DRASTIC method. 10th Int. Hydrogeol. Congr. Greece 387-396

34. Loredo-Portales R, Bustamante-Arce J, González-Villa HN, Moreno-Rodríguez V, Rio-Salas D, MolinaFreaner R, González-Méndez F, Archundia-Peralta B, D (2020) Mobility and accessibility of Zn, Pb, and As in abandoned mine tailings of northwestern Mexico. Environ Sci Pollut Res. https://doi.org/10.1007/s11356-020-09051-1

35. McKenna PB, Lechner AM, Phinn S, Erskine PD (2020) Remote Sensing of Mine Site Rehabilitation for Ecological Outcomes: A Global Systematic Review. Remote Sens 12:3535. https://doi.org/10.3390/rs12213535

36. Oke SA (2020) Regional Aquifer Vulnerability and Pollution Sensitivity Analysis of Drastic Application to Dahomey Basin of Nigeria. Int J Environ Res Public Health 17:2609. https://doi.org/10.3390/ijerph17072609

37. Development Team QGIS (2019) QGIS Geographic Information System. Open Source Geospatial Foundation Project

38. Rivera-Uria MY, Ziegler-Rivera FRA, Diaz-Ortega J, Prado-Pano B, Romero M, F (2018) Effect of an acid mine spill on soils in Sonora River Basin: Micromorphological indicators. Spahish J Soil Sci 8. https://doi.org/10.3232/SJSS.2018.V8.N2.0

39. Roldán-Quintana J (1991) Geology and chemical composition of the Jaralito and Aconchi batholiths in east-central Sonora, Mexico. Geological Society of America, 254,., in: Studies of Sonoran Geology. pp. $69-80$

40. Saravanan S, Jegankumar R, Selvaraj A, Jacinth Jennifer J, Parthasarathy KSS (2019) Utility of Landsat Data for Assessing Mangrove Degradation in Muthupet Lagoon, South India. Coastal Zone Management. Elsevier, pp 471-484. https://doi.org/10.1016/B978-0-12-814350-6.00020-3

41. Schimmer R (2008) A REMOTE SENSING AND GIS METHOD FOR DETECTING LAND SURFACE AREAS COVERED BY COPPER MILL TAILINGS 13

42. Simate GS, Ndlovu S (2014) Acid mine drainage: Challenges and opportunities. J Environ Chem Eng 2:1785-1803. https://doi.org/10.1016/j.jece.2014.07.021

43. Simmons S, Sawkings F (1983) Mineralogic and fluid inclusion studies of the Washington Cu-Mo-WBearing breccias pipe, Sonora Mexico. Econ Geol 78:521-526

44. Thapa R (2018) Sensitivity analysis and mapping the potential groundwater vulnerability zones in Birbhum district, India: A comparative approach between vulnerability models.Water Sci.23

45. Tiwari AK, Singh PK, De Maio M (2016) Evaluation of aquifer vulnerability in a coal mining of India by using GIS-based DRASTIC model. Arab J Geosci 9:438. https://doi.org/10.1007/s12517-0162456-0

46. Voutchkova DD, Schullehner J, Rasmussen P, Hansen B (2021) A high-resolution nitrate vulnerability assessment of sandy aquifers (DRASTIC-N). J Environ Manage 277:111330. https://doi.org/10.1016/j.jenvman.2020.111330 
47. Wang W, Liu R, Gan F, Zhou P, Zhang X, Ding L (2021) Monitoring and Evaluating Restoration Vegetation Status in Mine Region Using Remote Sensing Data: Case Study in Inner Mongolia, China. Remote Sens 13:1350. https://doi.org/10.3390/rs13071350

48. Werner TT, Bebbington A, Gregory G (2019) Assessing impacts of mining: Recent contributions from GIS and remote sensing. Extr Ind Soc 6:993-1012. https://doi.org/10.1016/j.exis.2019.06.011

49. Yin L, Zhang E, Wang X, Wenninger J, Dong J, Guo L, Huang J (2013) A GIS-based DRASTIC model for assessing groundwater vulnerability in the Ordos Plateau, China. Environ Earth Sci 69:171-185. https://doi.org/10.1007/s12665-012-1945-z

50. Zeng X, Liu Z, He C, Ma Q, Wu J (2017) Detecting surface coal mining areas from remote sensing imagery: an approach based on object-oriented decision trees. J Appl Remote Sens 11:015025. https://doi.org/10.1117/1.JRS.11.015025

51. Zuñiga-Hernández LG (2010) Estudio geológico, geoquímico y Metalogenético del cuadrángulo Huépac-Moctezuma. Centro-Noroeste de Sonora, México

\section{Figures}




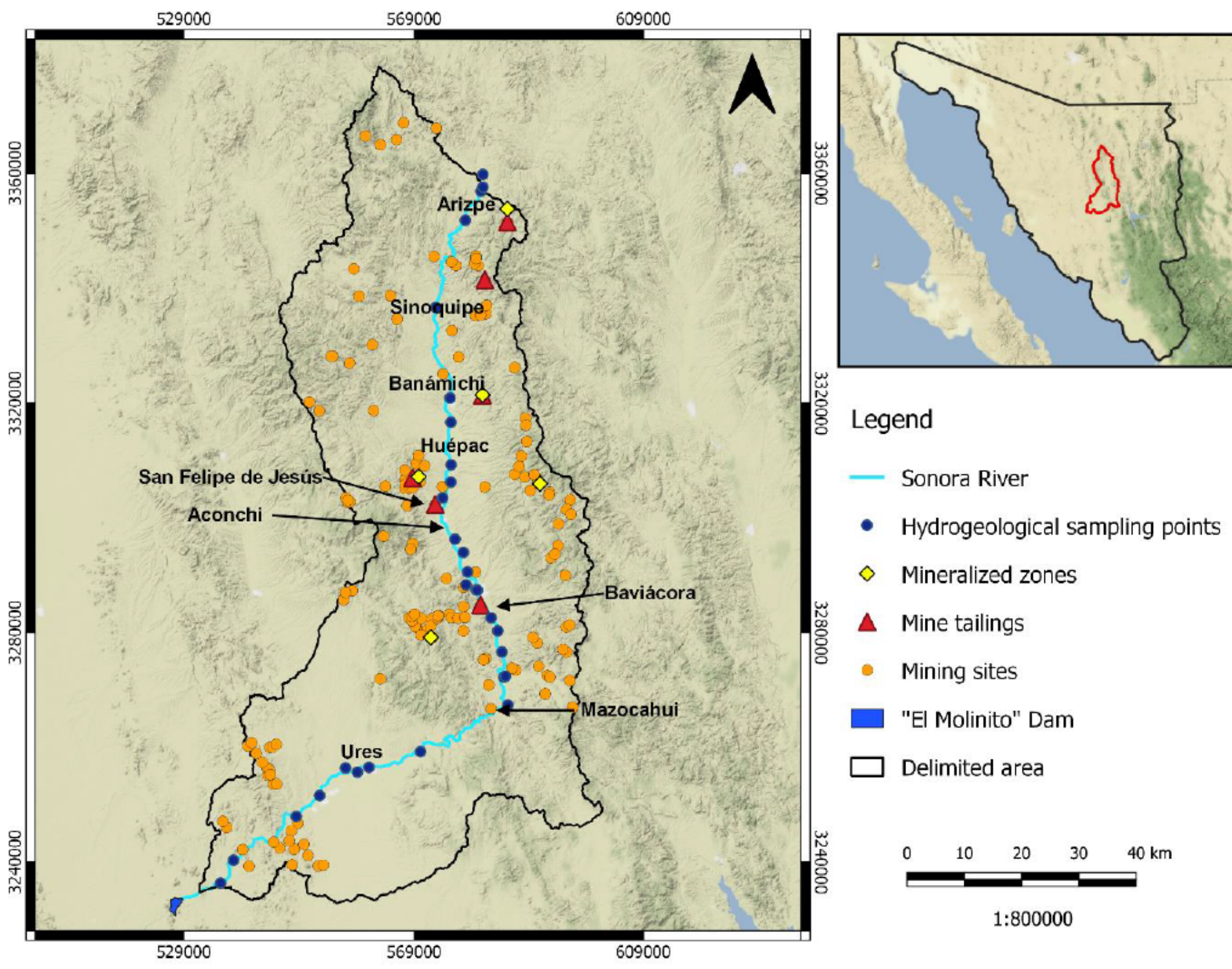

Figure 1

Study area corresponding to the Sonora River aquifer. The figure contains the municipalities, known mineralizes zones, mine tailings, mining sites and hydrogeological sampling points used to validate the results. 


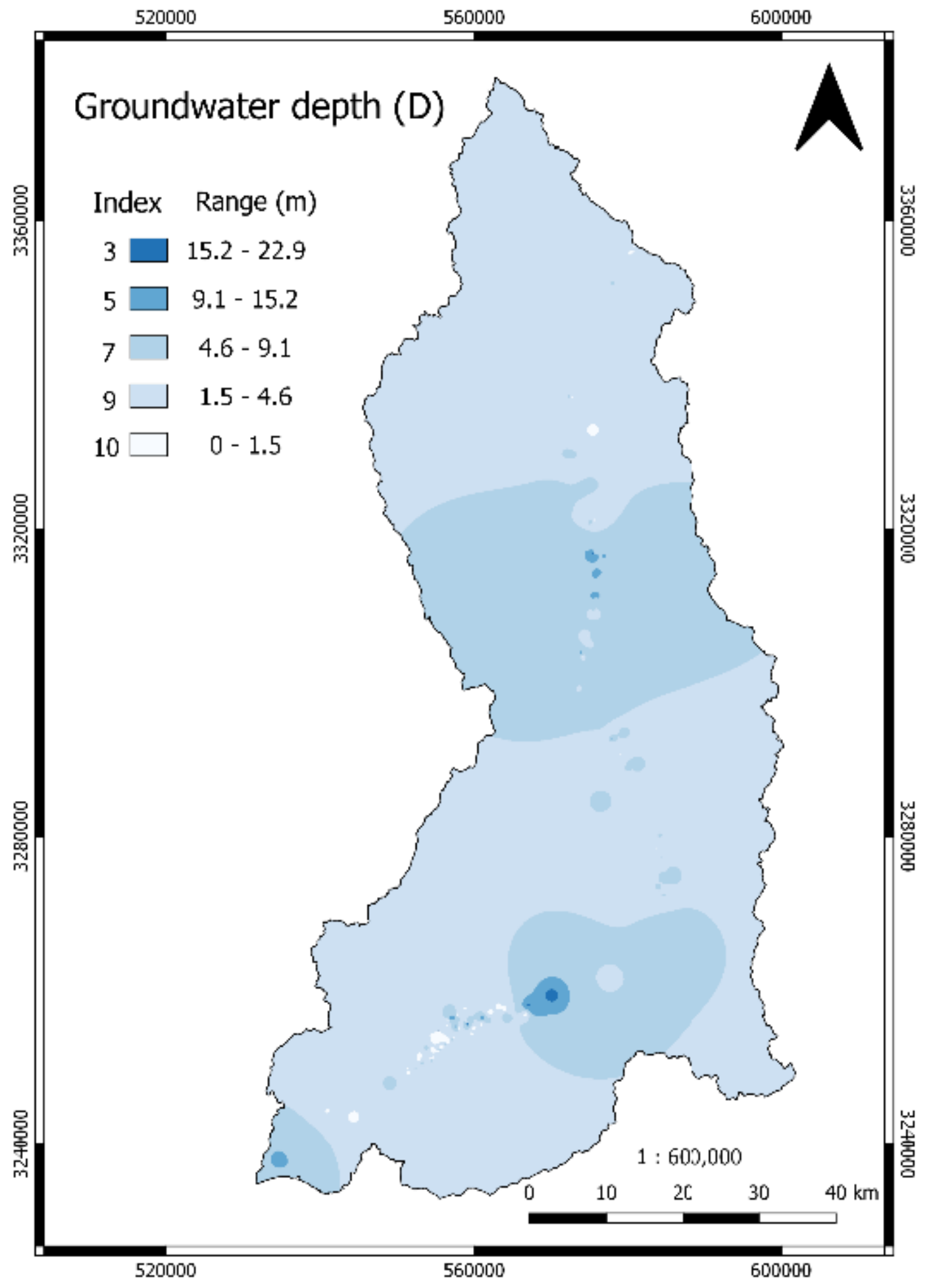

Figure 2

Groundwater depth in the Rio Sonora aquifer. 
$\begin{array}{cc}1 \square & 0-51 \\ 3 \square & 51-102 \\ 6 & 102-178\end{array}$

$\begin{array}{cc}\text { Index } & \text { Range (mm) } \\ 1 \square & 0-51 \\ 3 \square & 51-102 \\ 6 & 102-178\end{array}$

$\begin{array}{cc}\text { Index } & \text { Range (mm) } \\ 1 \square & 0-51 \\ 3 \square & 51-102 \\ 6 & 102-178\end{array}$

$\begin{array}{cc}\text { Index } & \text { Range (mm) } \\ 1 \square & 0-51 \\ 3 \square & 51-102 \\ 6 & 102-178\end{array}$

్్ㅇ్ల

Recharge (R)

옳

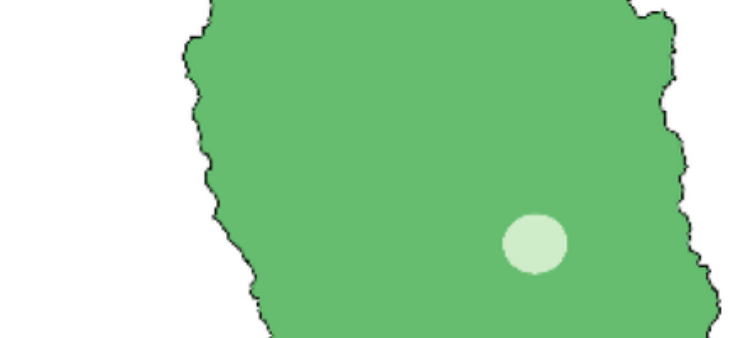

A

ㅆ

高
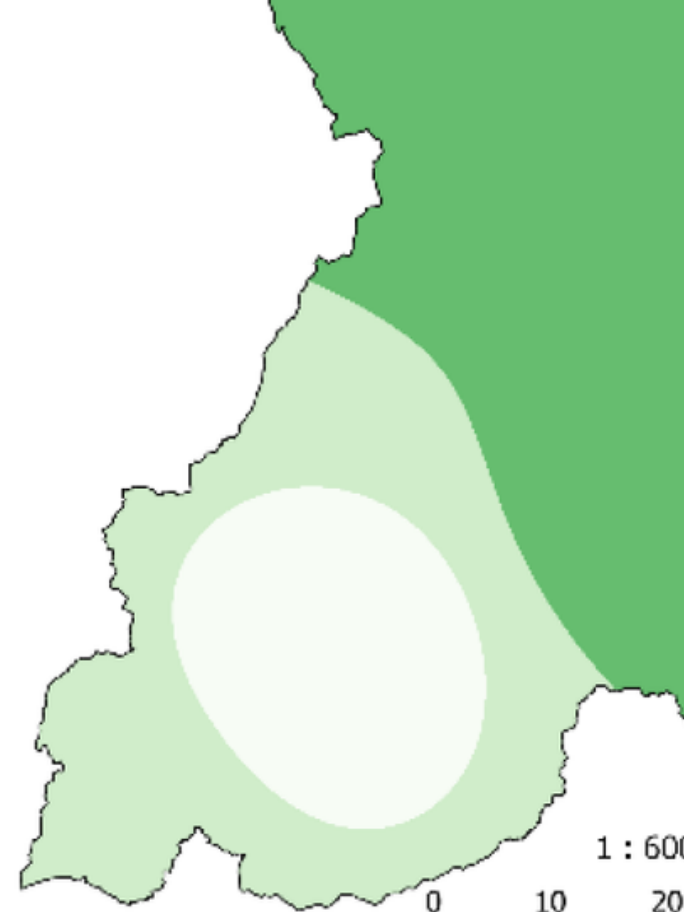

520000

560000

600000

\section{Figure 3}

Recharge (R). 


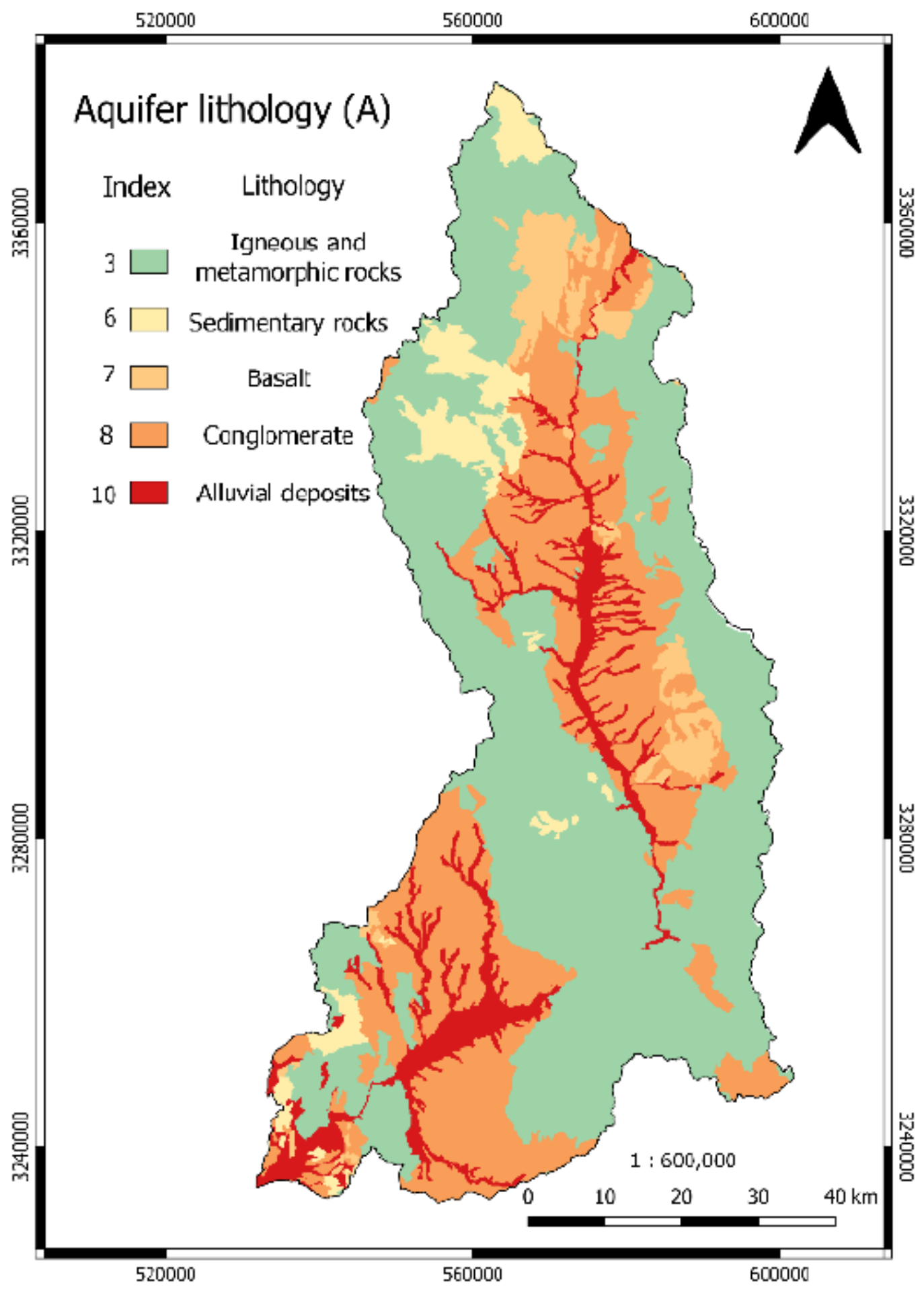

Figure 4

Aquifer media (A). 


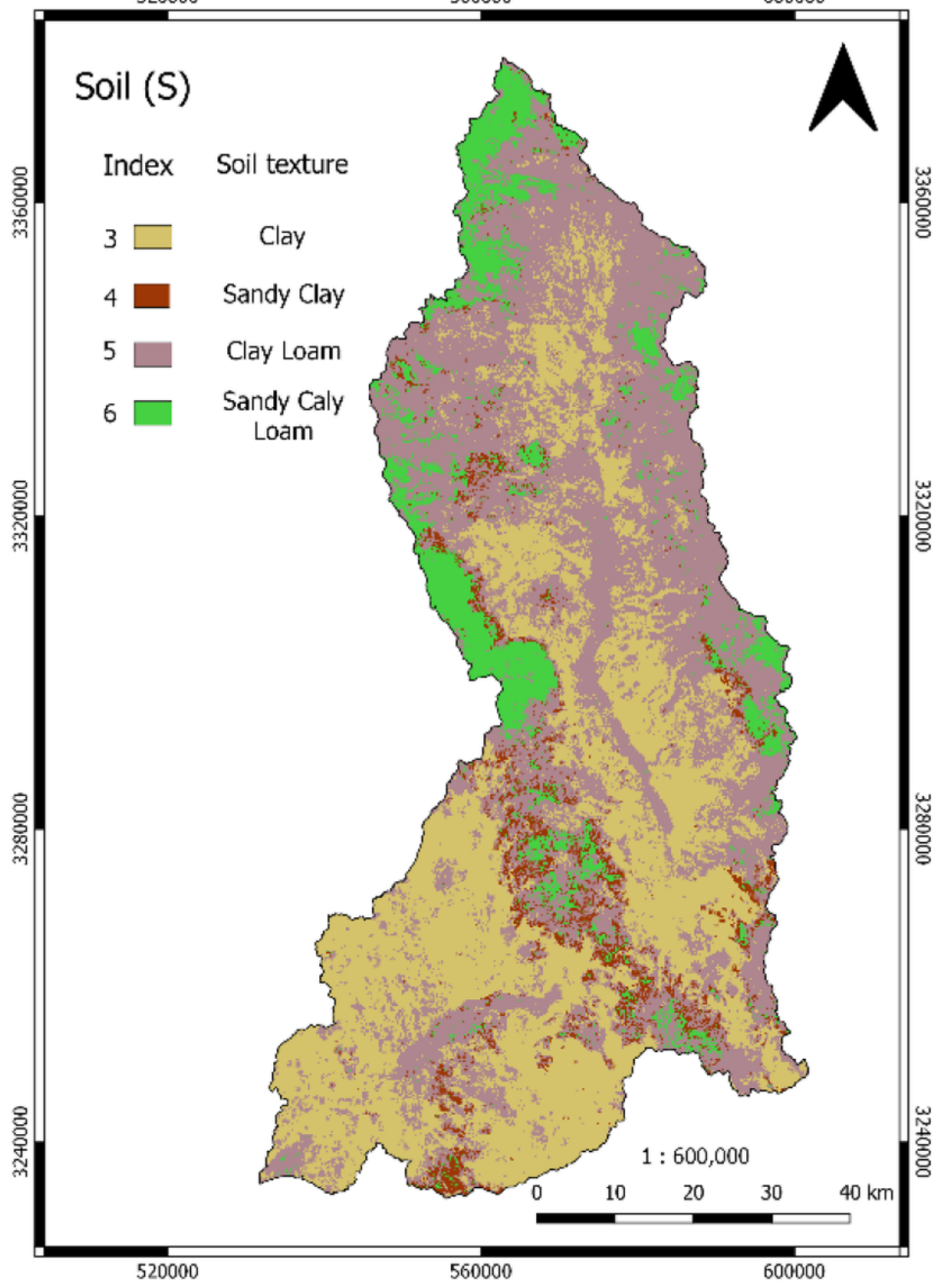

Figure 5

Soil (S). 


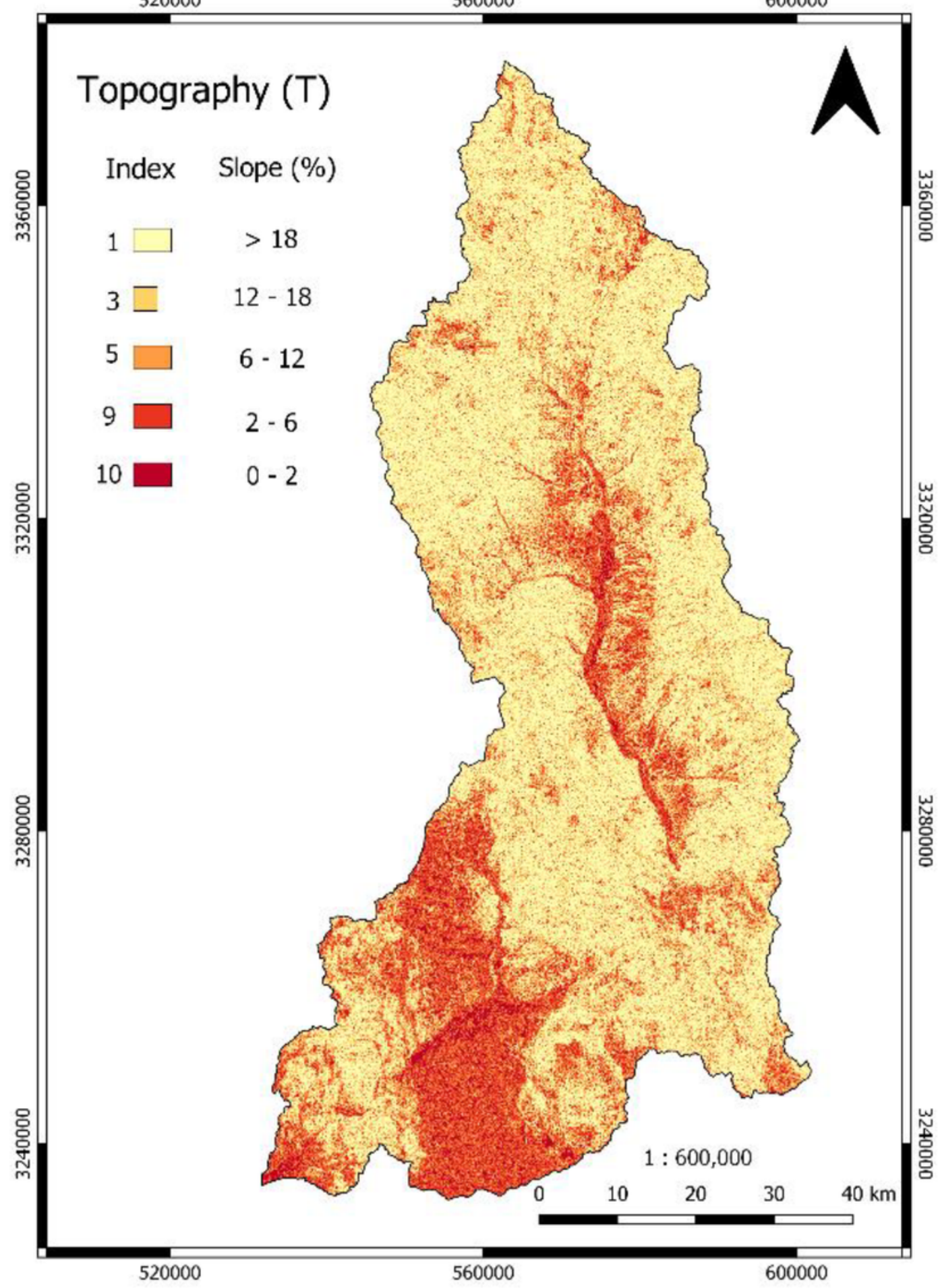

Figure 6

Topography (T). 


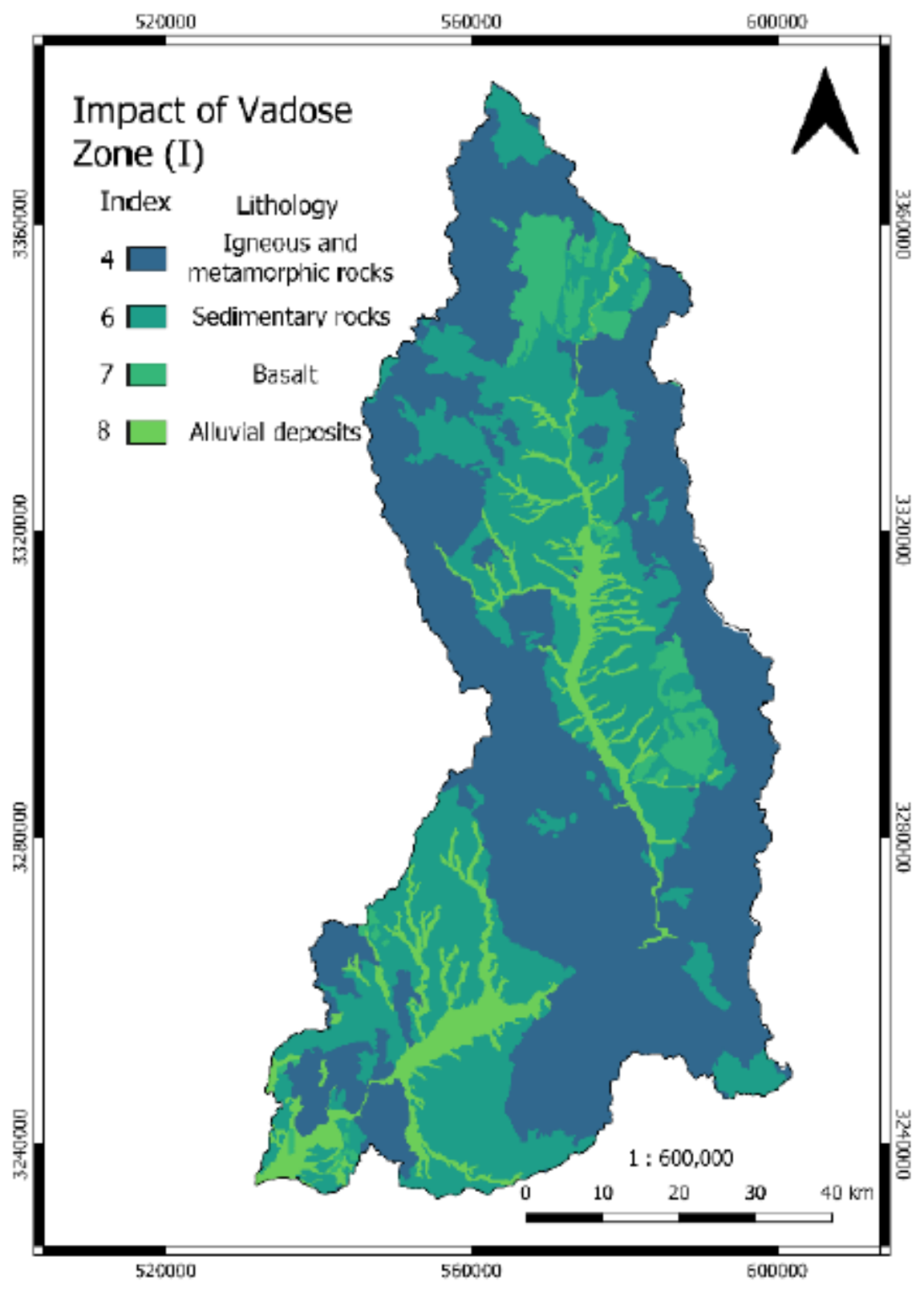

Figure 7

Impact of the vadose zone (I). 


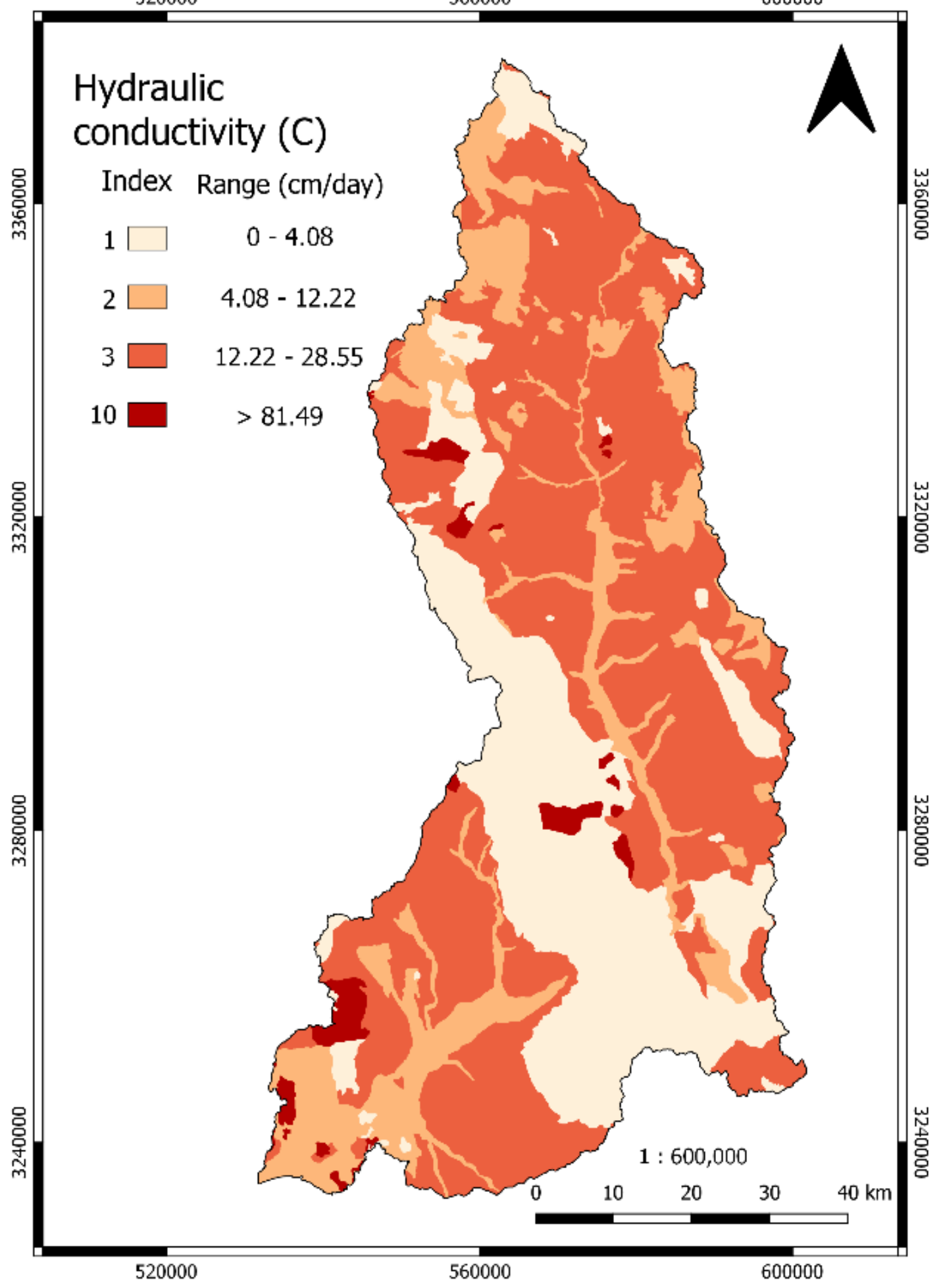

Figure 8

Hydraulic Conductivity (C). 


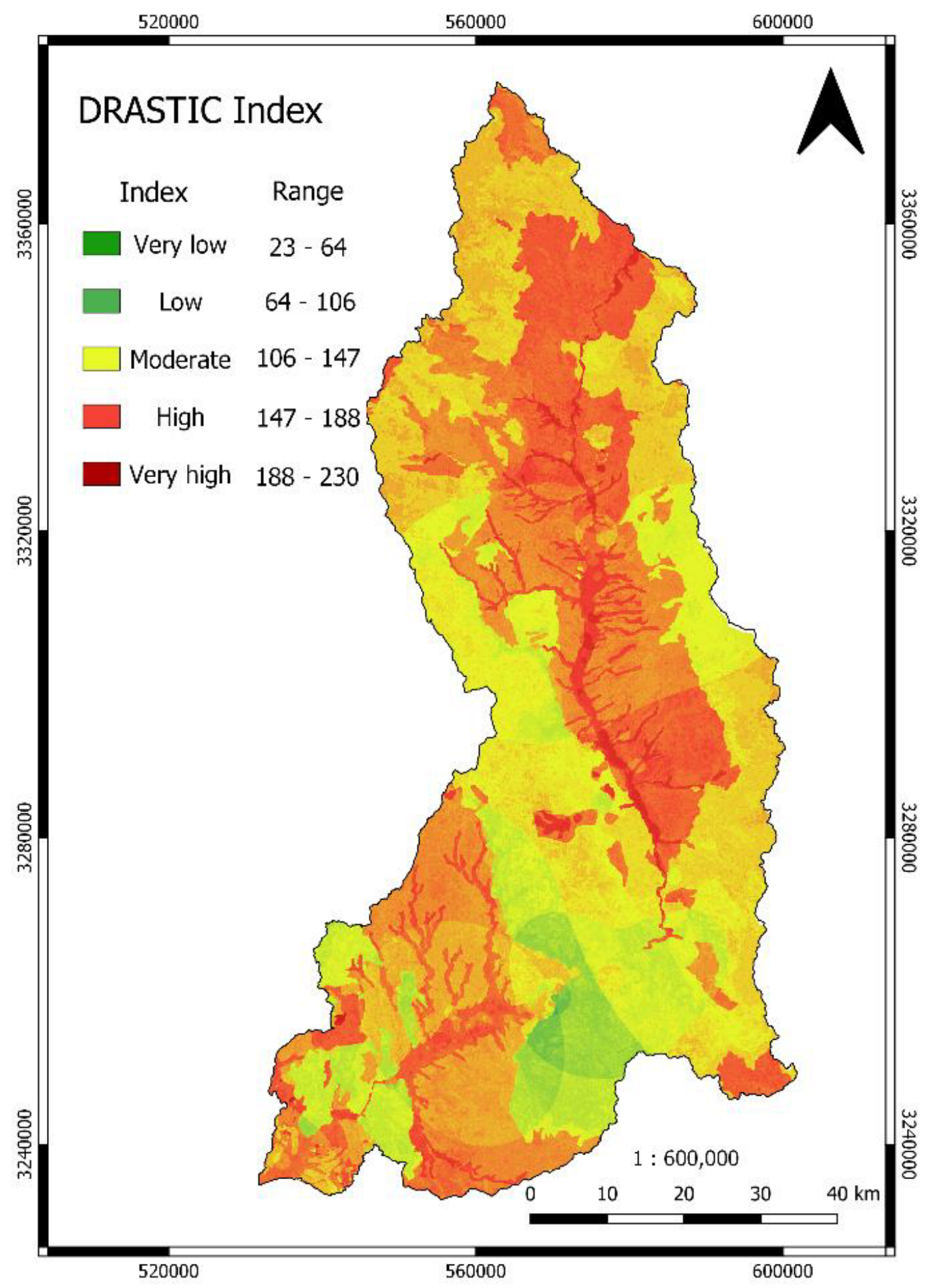

Figure 9

The Rio Sonora aquifer DRASTIC vulnerability map. 


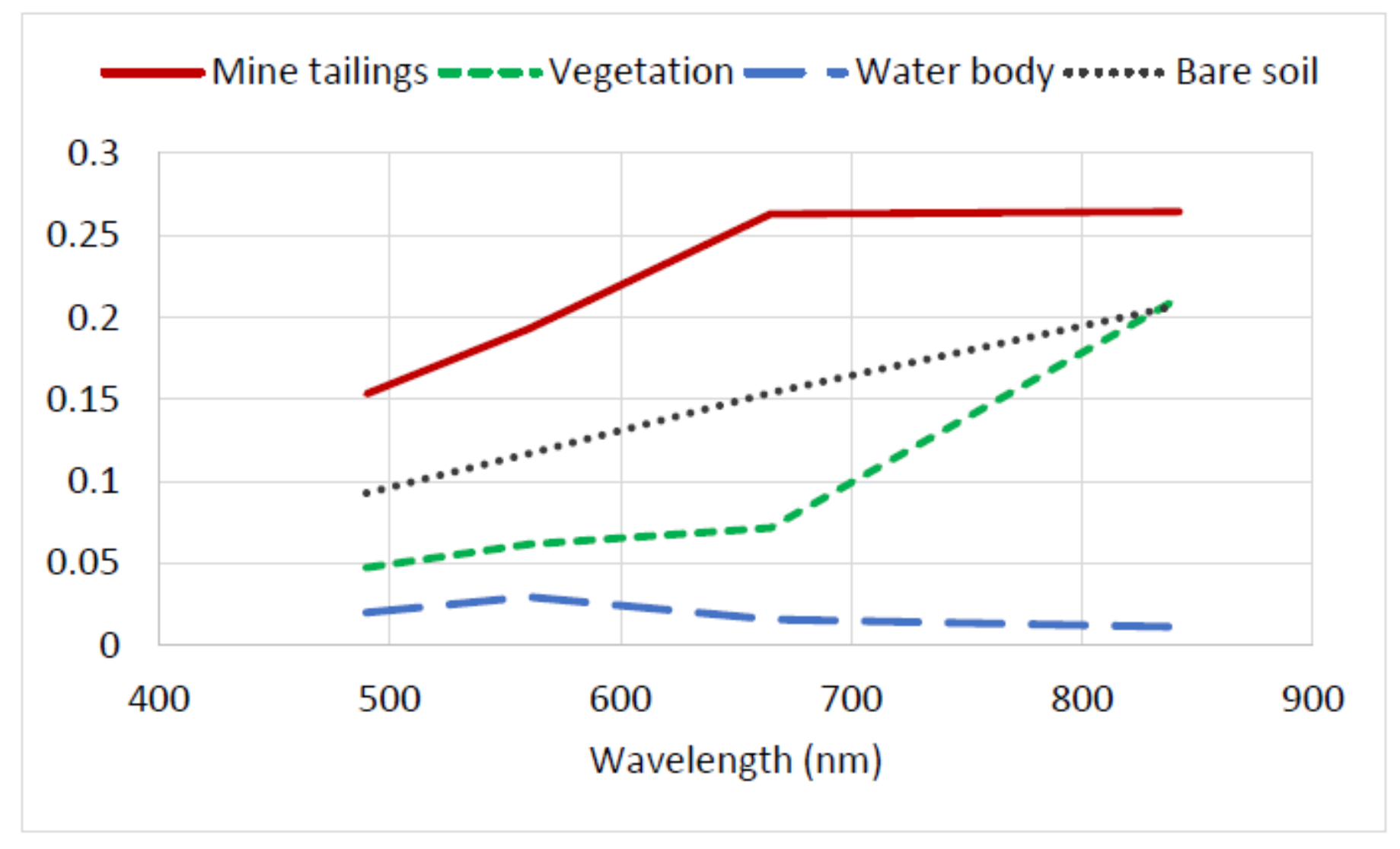

Figure 10

Spectral curves for representative surface features in the Sentinel 2 image 


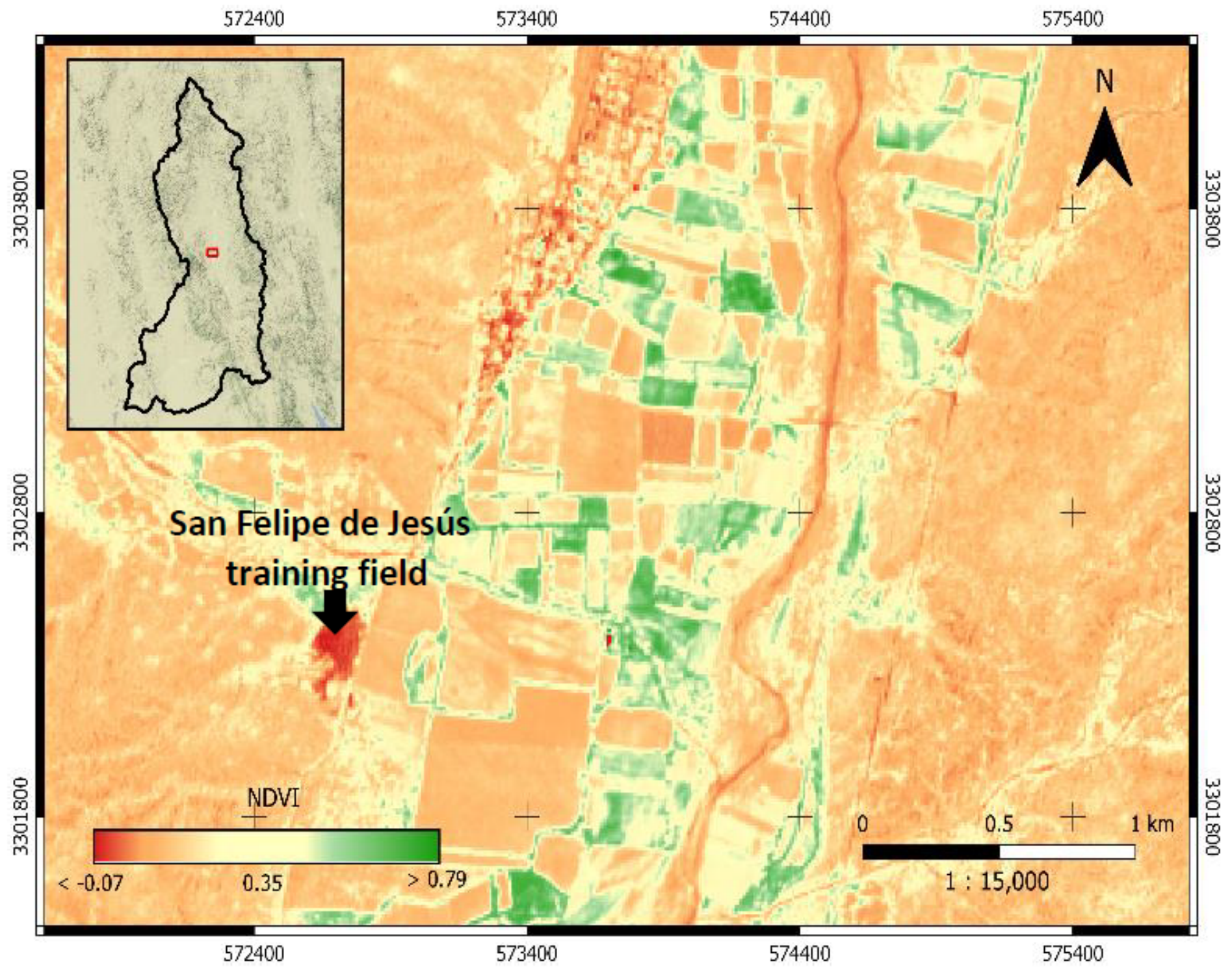

Figure 11

NDVI at a portion of the study site and the San Felipe de Jesús training field. 


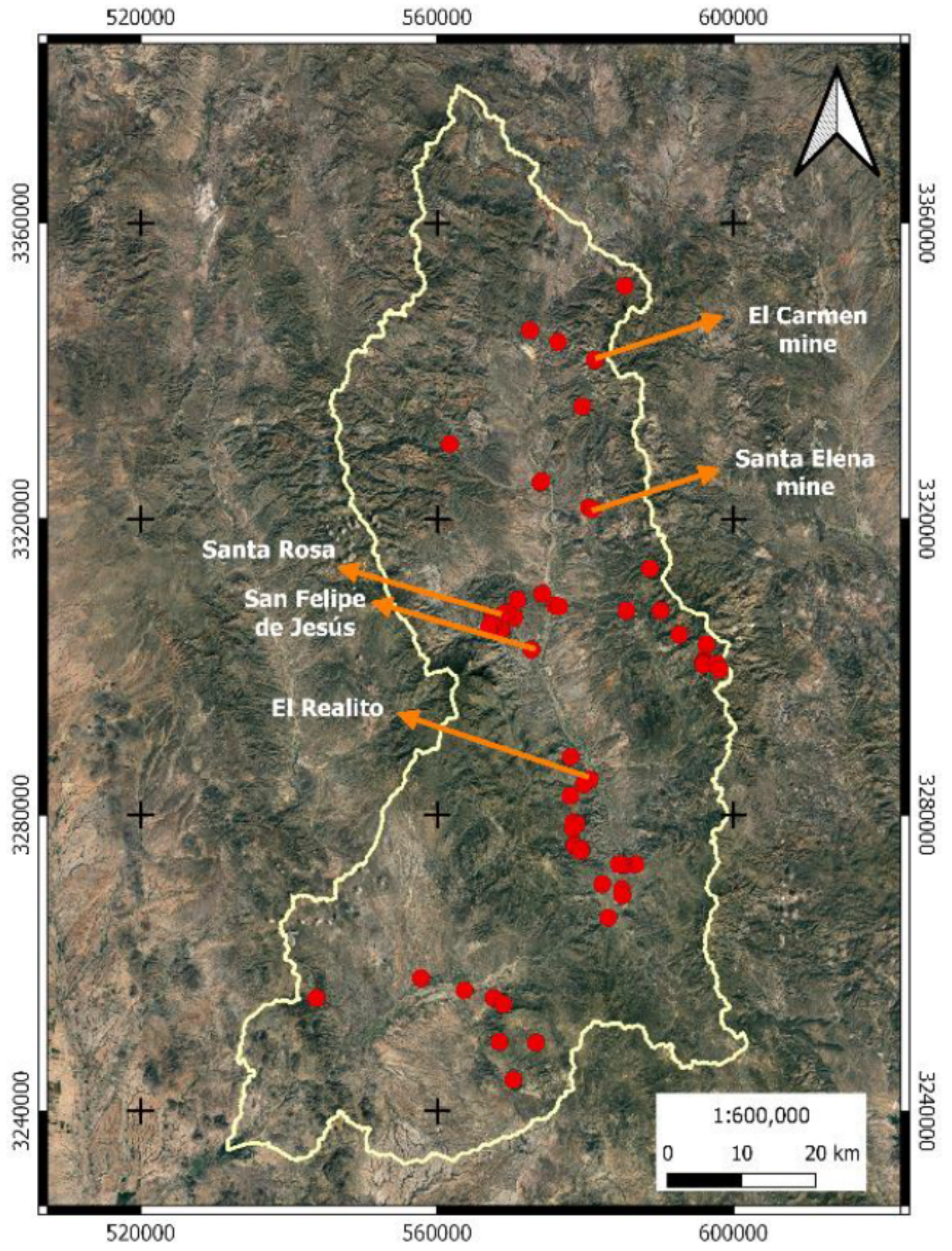

Figure 12

Possible sources of metallic pollution detected by remote sensing and training fields. 


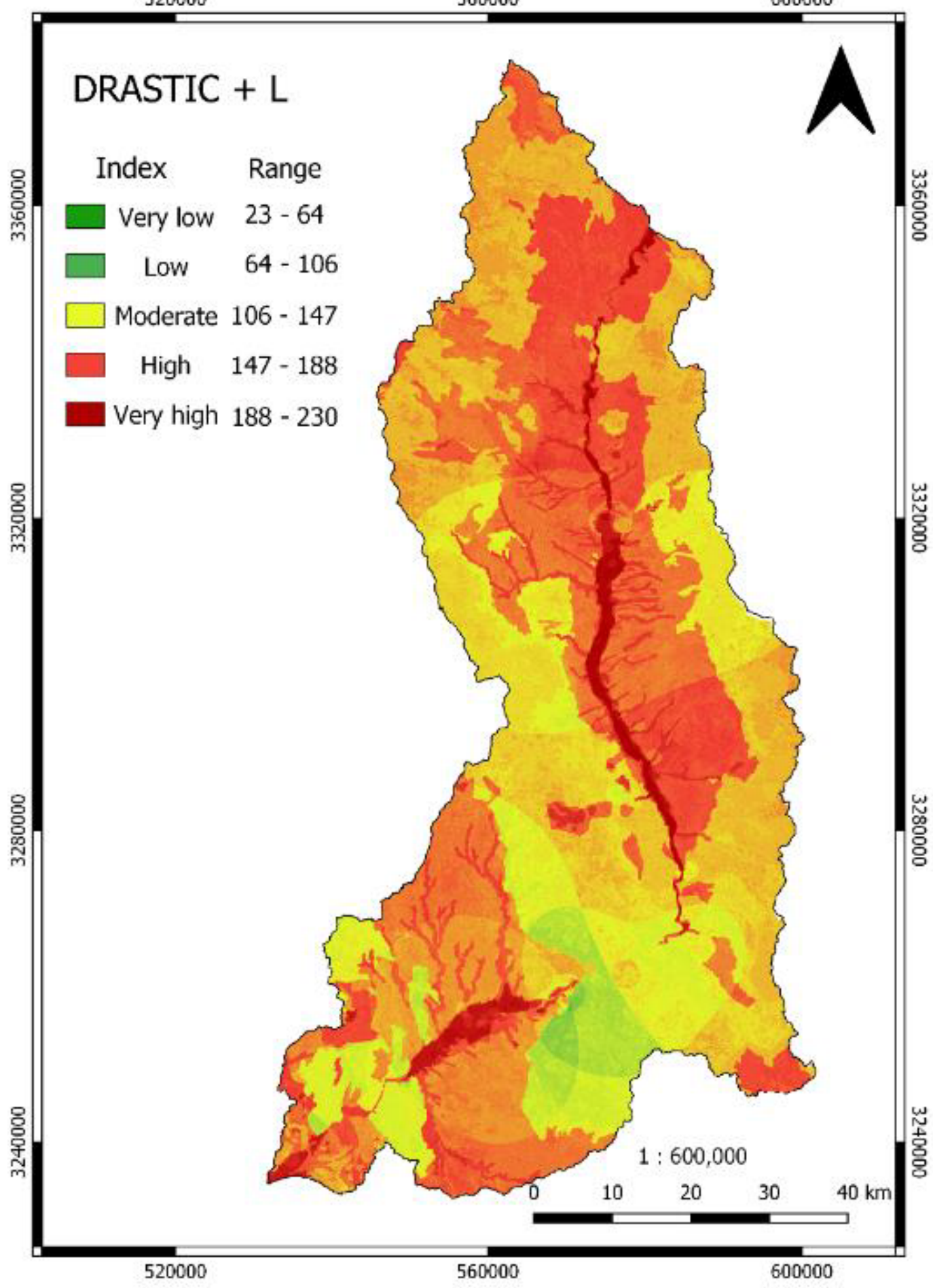

Figure 13

The Sonora River DRASTIC+Lu index. 


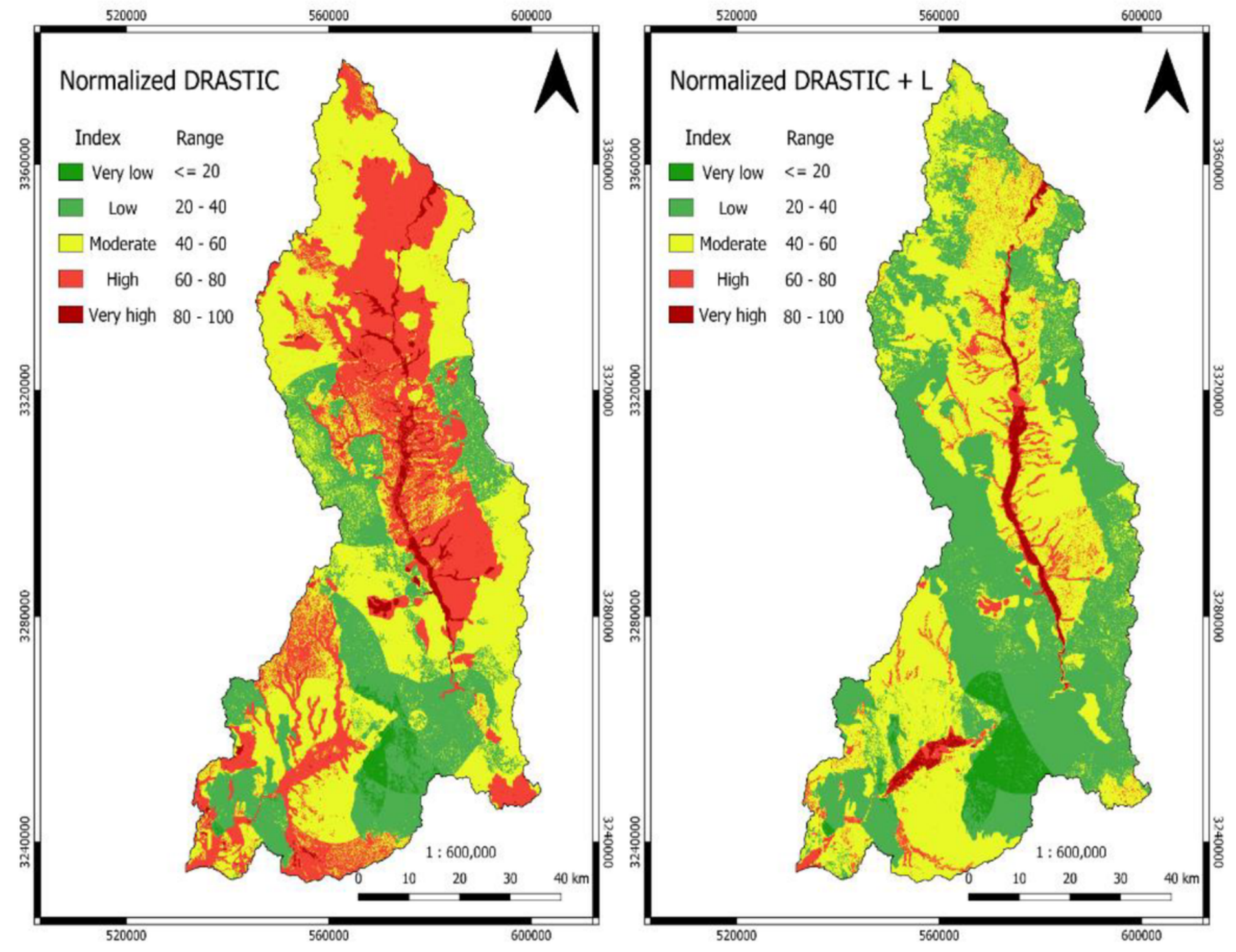

Figure 14

Normalized vulnerability maps (on a scale of 1 to 100) obtained by the DRASTIC and DRASTIC+Lu methods are shown in Figure

\section{Supplementary Files}

This is a list of supplementary files associated with this preprint. Click to download.

- SupplementaryMaterial.docx 